\title{
Impact of Microfinance Banks' Credit on the Performance of Small and Medium Scale Enterprises in Oyo State
}

\author{
Olusegun Samuel AREMU \\ Department of Banking and Finance, School of Business, The Polytechnic, \\ Ibadan, Oyo State, Nigeria. E- mail: pstsoaremu@yahoo.co.uk \\ Samuel Oluwapelumi OLOFINLADE \\ Department of Finance, Faculty of Management Science, Ekiti State \\ University, Ado-Ekiti, Ekiti State, Nigeria. E-mail: olofin73@gmail.com
}

\begin{abstract}
The contribution of microfinance banks' credit to the performance of small and medium scale enterprises in Nigeria has been an issue that has gained momentum among scholars of repute. Different studies have been conducted in this light and their findings have been generically validated over time and have become basis for further researches. However, much studies have not been articulated towards underpinning impact of microfinance credit on performance of small and medium scale enterprises, with profitability and market size as performance indicators. This study was anchored on growth theory, propounded by Harold (1939) and Dolmar (1946). Two hypotheses were formulated and tested using regression analysis. The results showed that microfinance bank credit had significant impact on profitability and market size of small and medium scale enterprises. It was recommended that government should create an enabling environment for business opportunities to thrive in the country and that the conditions for accessing the credit facilities by the small and medium scale enterprises should be less stringent.
\end{abstract}

Keywords: Performance, Small and Medium Scale Enterprises, Profitability, Market Size, Credit Facilities

JEL Classification: G34; E59; G21 


\section{Introduction}

In order to promote and achieve effective performance of Small and Medium Enterprise (SME) sector, the contribution of the Microfinance banks in terms of granting credit facilities and other assistance of relevance becomes sacrosanct. Although, optimizing the performance of the economy could be predicated on the contribution of the small and medium scale enterprises. Conversely, globally SMEs carry diverse connotations. SMEs perform the role of economic development and provision of jobs in a country. Small and medium scale enterprises (SMEs) make a significant impact by improving a country's economic performance (Anyanwu, 2001; Afolabi, 2012; Uremadu et al., 2014);SMEs result in creating more direct jobs compared to big enterprises; and they are training grounds for those who want to develop technical and entrepreneurial skills (Kira, 2013; Uremadu et al., 2014).

According to Quaye et al. (2014), Microfinance banks have succeeded in the provision of finance and gradually helping SMEs to acquire financial assistance. Competence, effective, and efficient Microfinance banks serve the financial needs of informal sectors. Many microfinance institutions acknowledge that the market is large enough to accommodate the traditional and universal banks. SMEs are determined to dominate and have their market share before the open market competition is in full effect in a country (Uremaduet al., 2014; Theriou, 2016; Havlicek et al., 2013; Breckova and Havlicek, 2013; Anureev et al., 2017).

There is a notion that microfinance banks are bad risk and that their services may not be sustainable and aid the survival of small and medium scale enterprises and as a result therefore have slight concern for funding the sector. This is in addition of to issues of high contract costs and short length of payback period when funding is taken into consideration. Since a robust economic growth cannot be achieved without putting in place well focused programmes to reduce poverty through empowering the people by increasing their access to formal financial services. The Central Bank of Nigeria in 2005 as part of its banking reform agenda started licensing Microfinance Institutions (MFIs) aimed at providing financial services to small and medium scale enterprises that are not served by the conventional financial institutions (Ozioko,2010). Emphasis, therefore, shifted from large-scale industries to SMEs, which have the potentials for developing domestic linkages sufficient for rapid and sustainable industrial development.

According to Yarron (1998), Nigeria is blessed with remarkable entrepreneurs who need support at Micro, Small and Medium Scale Enterprises levels as well as big businesses. A common characteristic of these enterprises is their need for good financing. An obvious and probable development of Small and Medium Scale Enterprises (SMEs) in Nigeria is attached to the backing of banks through issuing of bank credits to SMEs. Annually, loans to SMEs appreciate and largely greater than the progression in the total of bank credit. A known way of raising capital for SMEs is through the process of borrowing from financial institutions.

Credit is a financial facility that allows a person or business entity to borrow money, to buy products and pay it back within the prescribed period. The problem faced by Small and Medium Scale Enterprises (SMEs) in Nigeria can fundamentally be regarded as internal and external (Hamid and Susilo, 2010; Susilo, 2010).

According to Hamid and Susilo (2010) and Susilo(2010), the problems that could be regarded as internal factors are: (1) lack of capital, (2) limited human resources and (3) weak business networks and market penetration capability. In another vein, the external factors include the following/(1) the business environment is not yet conducive, (2) limited facilities and business infrastructure, (3) regional autonomy implication, (4) the nature of the product life time which is 
short, (5) lack of market access and (6) the implications of free trade. Requiring capital, SMEs want the backing of financial institutions most especially banks.

It is crystal clear from literature that the access to finance of most small and medium scale enterprises is still low. In essence, there are several issues generating this problem one of which is the profile of the prospective debtors of small and medium scale enterprises. It is obvious that most of the SMEs do not have what it takes to apply for financial assistance in terms of loans and advances from the banks. In this regard, feasibility study of the small and medium scale enterprises is considered by the microfinance banks and often times the SMEs are found unable to meet up with the basic requirements for accessing loans or other bank facilities (Hamid and Susilo, 2010). In the postulation of Susilo (2010) and Hamid and Susilo (2010), funding small and medium scale enterprises is highly crucial in order to ensure the promotion of workable economic progression and plummeting poverty in the country. There is need for government intervention which perhaps is a veritable tool for optimizing economic performance in Nigeria. The intervention could be in form of policy transformation through reduction in interest rate charged by microfinance banks, interest-free loans and other industrialization-oriented policies. This policy change would essentially ensure the stimulation of economy and promote performance of small and medium scale enterprises in Nigeria.

\section{Statement of the Problem}

The development of every country perhaps hinges on the performance of small and medium scale enterprises (SMEs). In the light of this, it is appalling that Nigeria has experienced poverty of mindset when it comes to developing and improving the performance of small and medium scale enterprises. The conduit by which the optimization of their performance can be ensured could have been through the granting of credit to them by the microfinance banks. However, most microfinance banks have not been forth-coming thus impairing the performance of these SMEs.

The microfinance banks though projects the willingness to help these SMEs, however, the stringent conditions attached to some of these credit facilities makes it inaccessible. Therefore, yearly, most of the small and medium scale enterprises do not seem to make any substantial progress over time. They have been stagnated in terms of performance. Most of them are even backward and thus considering quitting the business as the owners of such businesses could not meet up with their daily basic obligations. This problem of lack of access of small and medium enterprises to secure financial facilities by the banks should be addressed, or else, it could stunt the economic development of the country.

\section{Objectives of the Study}

The broad objective of the study was to examine the impact of microfinance banks' credit on the performance of small and medium enterprises in Oyo State, Nigeria. The specific objectives are to:

i. examine the impact of microfinance banks' credit on the profitability of small and medium scale enterprises in Ibadan, Oyo state, Nigeria.

ii. ascertain the impact of microfinance banks' credit on the market size of small and medium scale enterprises in Ibadan, Oyo State, Nigeria.

\section{Research Hypotheses}

In order to achieve the stipulated objectives of the study, the following hypotheses were formulated: 
i. there is no significant impact of microfinance banks' credit on the profitability of small and medium scale enterprises in Ibadan, Oyo state, Nigeria.

ii. there is no significant impact of microfinance banks' credit on the market size of small and medium scale enterprises in Ibadan, Oyo State, Nigeria

\section{Literature Review}

\section{Theoretical Framework}

This study is anchored on the theory promulgated by Harold (1939) and Dolmar (1946), and this is called the Harold Dolmar growth model. The supposition in the model is that, for steady state of progress, total demand must grow at the same rate as an economy's output capacity grows. The model has the following implications on this study, first there is a need for investment if an entrepreneur has to grow and this necessitates access to loans and savings given by MFIs This will facilitate more investment by SME owners. The implication is that despite the effort made to lend to entrepreneurs, their business prosperity is limited by the country and global economic performance.

As national economic performance grows the SMEs and members also perform well because there will be more business opportunities. The theory believes that the activities of the microfinance banks in form of credit provision, savings mobilization, insurance, training etcetera serves as a useful instrument for snowballing the creative capacity of the users. The essence of microfinance banks in stimulating development has been widely discussed in literature. Bencivenga and Smith (1991) posited that development of microfinance banks and effective financial intermediation add value to economic performance of rural area by channeling savings to high productive activities and reducing risks that may endangered productive capacity of SMEs.

In a study conducted by Dionco-Adetayo et al. (2006) on how the programme's promotion policy affects the development of small enterprises. The study aimed at identifying programmes, promote small-scale industries, assess them on how they meet their objectives and test the effects of these programmes on business growth. The study was conducted in Lagos State where industrial and commercial activities are highly concentrated. The independent variables consist of: small business development measured by the size of the amount of labour, business structure and technology development. On the other hand, the dependent variable is company promotion policy programme that is operated and measured with Likert scale. Descriptive and inferential analyses were used to analyse the data obtained through structured questionnaires. It was revealed that the corporate promotional programmes focused on the development of small industry in terms of technical aspects, education, training, technology adaptation and commercialization and information services. The awareness level of SMEs of such programmes is still low which hampered small industries in utilizing these programmes.

In another study carried out by Babagana (2010) and Hassan and Olaniran (2011) examined the impact of the role played by microfinance banks (MFBs) in promoting the performance of SMEs in Nigeria. The research results indicated a positive impact of MFBs in fostering the performance of SMEs in the country. Akingunola (2011) also examined the specific financing options available to SMEs in Nigeria and their contributions to economic growth. Financing aid agencies have contributed to the development of SMEs in Nigeria with particular reference to the Industrial Development Center (IDC). Their SME financing aid agencies proved that they were able to increase the output of SMEs.

Obasan and Arikewuyo (2012) examined the effects of pre-post bank consolidation on the accessibility to finance by SMEs in Nigeria. Research results indicated that prior to banking 
consolidation, access to SMEs to get credit was very difficult and this curtailed the growth of SMEs in Nigeria. With banking consolidation, the impact on the growth of SMEs and economic growth of Nigeria tended to be positive. Ahiawodze and Adade (2012) investigated the effects of the company's access to credit for Small and Medium Enterprises SMEs in Ho Volta Region of Ghana using both surveys and econometric methods. The survey involved a sample of 78 SMEs in manufacturing sector of the Ho Municipality. Econometric model defined the company's growth as the dependent variable and the independent variables included access to credit, total investments, age of the company, the initial capital, the level of education and the annual turnover of the company. Both surveys and econometric results showed that access to credit provided a significant positive effect on the growth of SMEs in Ho-city of Ghana.

Joseph and Dansu (2013) examined the relationship between business risk and sustainability of SMEs in Nigeria. They asserted that SMEs faced a number of risks that require risk management efforts that are objective and transparent. Primary data were generated from fifty (50) SMEs in Lagos State. Data analyses and hypotheses testing were done using Chi-square and descriptive statistics. The results showed that the risk management strategies of SMEs did have a positive impact on the sustainability of their businesses.

Ogujiuba, et al., (2013) Katua, (2014) analysed the availability of credit for small and medium enterprises in Nigeria and the importance of new authorized capital for SMEs. Abereijo and Fayomi (2005) also examined innovative approaches to financing SMEs across the world, especially private equity financing in order to identify best SMEs practices. It was found that there were still many challenges for banks across the world to overcome difficulties in implementing SMEs credit scheme, challenges related to cash flow, structuring investments, increased monitoring / value, liquidity and exit strategies.

Kira(2013), Quaye et al. (2014) and Katua (2014) conducted a study on the effect of bank loans to SMEs on economic growth of the country. They observed that though Small and Medium Enterprises are potential for creating value-addition, in reality, they have not been maximally developed as evidenced by many shortcomings that hamper SMEs to flourish. One significant factor is capital (investment). This hampers SMEs from raising the scale of production and expansion. The study however found a positive relationship between easy access for SMEs to credit and economic growth (Kira, 2013; Quayeet al., 2014; Katua, 2014).

\section{Concept of performance}

Performance according to Obiwuru, Okwu, Akpa and Nwankwere (2011) refers to ability of an organization to achieve such objectives as high profit, quality product; large market share, good financial results and survival at pre-determined time using relevant strategies for action. Consequently, Wang, (2010) viewed performance as product accomplishments, results and achievements in an organization. Williams and Andersons, (1991) also defined performance as employee's achievement level in his/her responsibilities and duties assigned in the workplace. Understanding determinant factors of SMEs performance is considered an important area of focus in enterprises (Rosli, 2011). This is because SMEs contribute to employment growth at a higher rate than larger firms. Anastasia (2008) posited that organizational performance can be measured by effectiveness, efficiency, satisfaction and innovation of products. Apolot (2012) in his study measured organizational assessments of performance in sales growth, customer satisfaction and profitability in their businesses. This study therefore adapts the definition of both Apolot (2012) and Anastasia (2008). 


\section{Concept of Microfinance}

Microfinance is a poverty alleviation tool which has gained worldwide recognition since the 1990s and proven to have positive impact on poverty levels and entrepreneurship development in developing countries (Hossain et al, 2008). Microfinance is the provision of financial services to the poor, aiming at empowering low income population by providing them with access to credit and other financial services.

Through MFIs, the poor can obtain collateral-free loans at relatively low interest rates and use the money for creating microenterprises (small businesses owned by poor people), funding children's education and improving households, among others. Aside from microcredit, MFIs have also developed numerous financial services such as micro-insurance and micro-mortgage designed to accommodate the poor's financial needs. Most of these institutions have also required their clients to open up savings accounts which could be used for emergency and investment purposes (Carr \& Tong, 2002).

The Canadian International Development Agency (CIDA) defined microfinance as the provision of a broad range of financial services to poor, low income households and micro enterprises usually lacking access to formal financial institutions (CIDA,2002).It is the provision of financial services and the management of small amounts of money through a range of products that are targeted at the poor people. This product includes loans, savings, insurance et cetera (United Nation, 2005). According to Almeyda and Branch (1999), micro finance is the provision of credit, savings and other financial services to lower-income groups. In addition, Otero (1999) defined microfinance as the provision of financial services to low-income poor and very poor selfemployed people. Microfinance came into being from the appreciation that micro-entrepreneurs and some poorer clients can be 'bankable', that is, they can repay both the principal and interest on time and also make savings provided financial services are tailored to suit their needs.

\section{Concept of Microcredit}

According to Micro-credit Summit (2002), Microcredit is the extension of small loans to entrepreneurs too poor to qualify for commercial bank credit. It is the provision of cash and in kind loans in smaller amounts to micro, small entrepreneurs meant to improve their business operations. Sinha and Matin (1998) described microcredit as small loans, whereas microfinance is appropriate where NGOs and Microfinance Institutions (MFIs) supplement the loans with other financial services such as savings, insurance, etcetera. Thus microcredit is a component of microfinance in that it involves providing credit to the poor. Credit however provides the basis for increased production efficiency through a specialization function (Kimemia, 2004).

\section{Concept of SME in Nigeria}

Small scale businesses, Small scale industries and small scale entrepreneurship are often used interchangeably to mean a Small and Medium Scale Enterprise. In Nigeria and worldwide, there seems to be no specific definition of small business. Different authors, scholars, and schools have different ideas as to the differences in capital outlay, number of employees, sales turnover, fixed capital investment, available plant and machinery, market share and the level of development, these features equally vary from one country to the other.

In Nigeria, for example, the Third National Development plan defined a small scale business as a manufacturing establishment employing less than ten people, or whose investment in machinery and equipment does not exceed six hundred thousand naira (Kayode, 2010). Similarly, Central Bank of Nigeria (CBN) in its credit guidelines, classified small scale business as the businesses with an annual income/asset of less half a million naira $(\$ 500,000)$ (Kayode, 2010). Also, the Federal Government Small Scale Industry Development Plan of 1980 defined a small 
scale business in Nigeria as any manufacturing process or service industry with a capital not exceeding $\$ 150,000$ in manufacturing and equipment alone. In the same vein, the Small Scale Industries Association of Nigeria (1973) also defined small scale business as those having investment (i.e. capital, land building and equipment of up to $\$ 60,000$ (pre-SAP Value) and employing not more than fifty persons. While, the Federal Ministry of Industries defined it as those enterprises that cost no more than $\$ 500,000$ (pre-SAP Value) including working capital to set up. In addition, the Centre for Management Development (CMD) definition of small industry in the policy proposal submitted to the federal government in 1982 defined small scale industry as, "a manufacturing processing, or servicing industry involved in a factory of production type of operation, employing up to 50 full-time workers" (Kayode, 2010). While in the United States, the Small Business Administration (SBA) defines a small business as one that is independently owned and operated and is not dominant in its field and meets employment or sales standard developed by the agency (White \& Chacaltana, 2002).

\section{Methodology}

\section{Study Area}

The study was conducted in Oyo State, focusing on three Local Government Areas of Oluyole, Ibadan North and Ibadan South West. These three local governments were picked in Oyo State owing to the concentration of small and medium scale enterprises in these areas. The study essentially concentrated on the small and medium scale enterprises in these Local Government areas.

\section{Scope of the Study}

The study focused on the impact of microfinance banks' credit on the performance of small and medium scale enterprises in Ibadan North, Oluyole and Ibadan South West Local governments. The study intended to study only the microfinance banks' credit to SMEs.

\section{Research Design}

The design that was used in this study is the survey design of a descriptive nature. This involves the use of questionnaire to elicit response from the participants.

\section{Population and Sample of the Study}

The study population was the entire small and medium scale enterprises owners in of Oluyole, Ibadan North and Ibadan South West Local governments, while the sample size for the purpose of the study was 150 owners of small and medium enterprises.

\section{Procedure of Data Collection and Instrumentation}

Data was collected with the aid of a questionnaire. The questionnaire was administered on the owners of the small and medium scale enterprises in the selected local government areas. In the process of data collection, the researcher employed research assistants who helped in taking the questionnaires to these SME owners and their responses were retrieved after some of them have successfully filled the questionnaires.

Two instruments were used for this study. The first instrument used for this study was the microcredit and micro-savings questionnaire developed by Msoka (2014).Small and medium scale enterprises performance was measured by profitability, sales growth, innovation, effectiveness, efficiency and customer satisfaction questionnaire was adapted from Anastasia (2008). The instruments had a five-point rating scale of Strongly Agree, Agree, Disagree, Undecided and Strongly Disagree response options.

The model that as estimated for the study is presented below: 
$\mathrm{SP}=\alpha \mathrm{i}+\beta 1 \mathrm{IF}+\beta 2 \mathrm{IC}+\varepsilon$

Where:

SP- Information on SME's Performance

$\alpha \mathrm{i}$ - Intercept of the model

$\beta$ - The slope coefficient

IF- Information on Micro-loan

IC- Information on Micro-savings

$\varepsilon$ - Random disturbance term.

\section{Presentation of Result}

Hypothesis one states that there is no significant impact of microfinance banks' credit on the profitability of small and medium enterprises in Ibadan, Oyo state, Nigeria.

Table 1:Summary of Regression analysis showing the Impact of Microfinance Banks' Credit on the Profitability of Small and Medium Enterprises In Ibadan, Oyo State, Nigeria

\begin{tabular}{|c|c|c|c|c|c|c|}
\hline $\mathrm{R}$ & \multicolumn{3}{|l|}{ R Square } & $\begin{array}{l}\text { Adjusted R } \\
\text { Square }\end{array}$ & \multicolumn{2}{|c|}{$\begin{array}{l}\text { Std. Error of the } \\
\text { Estimate }\end{array}$} \\
\hline .457 & \multicolumn{3}{|l|}{.214} & .143 & \multicolumn{2}{|c|}{14.773} \\
\hline \multicolumn{7}{|c|}{$\mathrm{A} \mathrm{NOVA}$} \\
\hline Model & $\begin{array}{ll}\text { Sum of } \\
\text { Squares }\end{array}$ & Df & $\begin{array}{l}\text { Mean } \\
\text { Square }\end{array}$ & $\mathrm{F}$ & Sig. & Remark \\
\hline $\begin{array}{l}\text { Regression } \\
\text { Residual } \\
\text { Total }\end{array}$ & $\begin{array}{l}2368.426 \\
14663.562 \\
17031.998 \\
\end{array}$ & $\begin{array}{l}1 \\
149 \\
150 \\
\end{array}$ & $\begin{array}{l}543.456 \\
217.316\end{array}$ & 2.501 & .007 & Sig. \\
\hline
\end{tabular}

Table 1 shows the impact of microfinance banks' credit on the profitability of small and medium enterprises in Ibadan, Oyo State, Nigeria. The table further shows that a coefficient of multiple correlation $\left(\left(\mathrm{R}=.457 ; \mathrm{R}^{2}=.214\right.\right.$ and adjusted $\left.\mathrm{R}^{2}=.143 ; \mathrm{P}<.05\right)$. This implies that $14.3 \%$ of the variance was accounted for by the predictor variable (microfinance credit). The table also shows that the analysis of variance for the regression yielded $(\mathrm{F}=2.501 ; \mathrm{P}<.05)$. This implies that microfinance credit significantly predict profitability of the small and medium enterprises in Oyo State, Nigeria.

Hypothesis two states that there is no significant impact of microfinance banks' credit on the market size of small and medium enterprises in Ibadan, Oyo State, Nigeria.

Table 2: Summary of Regression Analysis Showing the Impact of Microfinance Banks' Credit on the Market Size of Small and Medium Enterprises in Ibadan, Oyo State, Nigeria.

\begin{tabular}{|c|c|c|c|c|c|c|}
\hline $\mathrm{R}$ & \multicolumn{3}{|l|}{ R Square } & $\begin{array}{l}\text { Adjusted R } \\
\text { Square }\end{array}$ & \multicolumn{2}{|c|}{$\begin{array}{l}\text { Std. Error of the } \\
\text { Estimate }\end{array}$} \\
\hline .312 & \multicolumn{3}{|l|}{.110} & .093 & \multicolumn{2}{|c|}{14.773} \\
\hline \multicolumn{7}{|c|}{ A $\mathrm{N} O \mathrm{VA}$} \\
\hline Model & $\begin{array}{l}\text { Sum of } \\
\text { Squares }\end{array}$ & Df & $\begin{array}{l}\text { Mean } \\
\text { Square }\end{array}$ & $\mathrm{F}$ & Sig. & Remark \\
\hline $\begin{array}{l}\text { Regression } \\
\text { Residual } \\
\text { Total }\end{array}$ & $\begin{array}{l}1054.951 \\
24159.154 \\
25214.105\end{array}$ & $\begin{array}{l}1 \\
149 \\
150\end{array}$ & $\begin{array}{l}720.214 \\
145.627\end{array}$ & 4.946 & .018 & Sig. \\
\hline
\end{tabular}

Table 2 shows the composite impact of microfinance banks' credit on the market size of small and medium enterprises in Ibadan, Oyo State, Nigeria. The table also shows a coefficient of multiple correlation $\left(\mathrm{R}=.312\right.$ and $\mathrm{R}^{2}=.110$ and adjusted $\left.\mathrm{R}^{2}=.093 ; \mathrm{P}<.05\right)$. This implies that $9.3 \%$ of the 
variance was accounted for by the predictor variable (microfinance banks' credit). The table also shows that the analysis of variance for the regression yielded ( $\mathrm{F}$-ratio $=4.946 ; \mathrm{P}<0.05)$. This implies that microfinance banks' credit has a significant positive relationship on the market size of small and medium enterprises in Ibadan, Oyo State, Nigeria.

\section{Discussion}

This study investigated impact of microfinance credit on the performance of small and medium scale enterprises in Oyo State, Nigeria. The performance indicators considered in this study are profitability and market size. Two hypotheses were tested in this study. Hypothesis one states that there is no significant impact of microfinance banks' credit on the profitability of small and medium enterprises in Ibadan, Oyo state, Nigeria. The result from this study shows that there was significant impact of microfinance credit on the profitability of small and medium enterprises in Oyo State, Nigeria. This was corroborated by Obiwuru, Okwu, Akpa and Nwankwere (2011).

Hypothesis two states that there is no significant impact of microfinance banks' credit on the market size of small and medium scale enterprises in Ibadan, Oyo State, Nigeria. The result shows that microfinance credit had significant impact on the market size of small and medium scale enterprises in Oyo State, Nigeria.

\section{Conclusion and Recommendations}

To ensure maximum performance of small and medium enterprises in terms of profitability and market size, there is need for microfinance banks to make available sustainable credit facilities to SMEs. This can be done in different forms through loans and advances. It is worthy of note that credit facilities of the microfinance banks would improve the market size and profit margin of the small and medium scale enterprises.

Therefore, subject to the above findings, the following recommendations are made:

I. That government should formulate policy that would make business activities of small and medium scale enterprises amenable and easy to conduct.

II. That credit facility which is interest friendly should be made available by the microfinance banks to small and medium scale enterprises.

III. The requirements for accessing credit facilities should be less stringent to allow every small and medium scale enterprise owner access credit without restriction.

IV. That adequate sensitization should be made by the microfinance banks to educate the owners of small and medium scale enterprises on the various facilities available and how to access it. 


\section{References}

Abereijo, O.A. and Fayomi, O. (2009(. Innovative Approach to SME Financing in Nigeria: A Review of Small and Medium Industries Equity Investment Scheme (SMIEIS). Journal of Social Sciences, 11(3), 219-227.

Afolabi, M.O. (2013). Growth Effect of Small and Medium Enterprise (SMEs) Financing in Nigeria. Journal of African Macroeconomic Review, 3(1), 192 - 205.

AGRA. (2013). Africa Agriculture Status Report: Focus on Staple Crops. Nairobi, Kenya: Alliance for a Green Revolution in Africa (AGRA)

Aguko, S. O., (2014) Value Chain Analysis and Organisational Performance of Beer Manufacturing Companies in Kenya School of Business, university of Nairobi.

Ahiawodze, A.K. and Adade, T.C. (2012). Access to Credit and Growth of Small and Medium Scale Enterprises in The Ho Municipality of Ghana. British Journal of Economics, $\quad$ Finance and Management Sciences, 6(2), $34-51$.

Akenbor, C. O., \&Okoye, E. I. (2011).An Empirical Investigation of Value-Chain Analysis and

Competitive Advantage in the Nigerian Manufacturing Industry. Africa Research Review, 5(23), 188-198.

Akingunola, R.O. (2011). Small and Medium Scale Enterprises and Economic Growth in Nigeria: An Assessment of Financing Options. Pakistan Journal of Business and Economic Review, 2(1).

Akoma, L., Adeoye, A. Binuyo, B., \&Akinwole, O. (2014). Leadership styles as Determinants of Small and Medium Scale Enterprises in Ogun State, Nigeria. Implication to Counselling and Management. Global Advanced Research Journal of Management and

Business Studies. 3(8); 388-393.

Akwara, A., Francis, A., Ngozi, F., Udaw, J., \&Odekina, F., (2014). Business and its Environment: Business Opportunities Open to Small-scale Enterprises During Political Transition Periods in Sub-Sahara Africa. Journal of Good Governance and Sustainable Development in Africa.Vol. 2, No 1 ISSN: 2346- 724X.

Anastasia, A. (2008). Measuring the Impact of Human Resources Management on Organizational Performance University of Macedonia (GREECE).Journal of Industrial Engineering and Management 01 (02): 119-142- ISSN: 2013-0853.

Anureev, V.S. (2017). Reconfiguration of Financial System Elements to Restore Economic Growth: The System Simplicity and Transformation towards State-Based and Corporate Based Types. European Research Studies Journal, 20(2A), 281-307.

Anyanwu, C.M. (2001). Financing and Promoting Small-Scale Industries: Concepts, Issues and Prospects. CBN Bullion, 25(3).

Apolot, S. (2012).Organizational Learning, Innovation and Small and Medium Enterprise (SMEs) Performance in Uganda. A research dissertation submitted to Graduate and Research Centre in Partial Fulfillment of the Requirements of the Award of Master of Science in Entreprenuership and Small Business Management of Makerere University.

Armstrong, M. (2009) A handbook of human resources management practice. London: kogan page.

Asikhia, O.U. (2009). Attitudinal Response of Small and Medium Scale Business Owners to Microfinance Banking in Nigeria. European Journal of Social Sciences, 11(4). 
Babagana, S.A. 2010. Impact Assessment of The Role of Micro Finance Banks in Promoting Small and Medium Enterprises Growth in Nigeria.Journal of economic development, 2(1), 65-74.

Baltacioglu, T., Ada, E., Kaplan, M. D., Yurt, O., \& Kaplan, Y. C. (2007). A new framework for $\quad$ service supply chains. The Service Industries Journal, 27(2),105-124.

Bamber, P., Abdulsamad, A. \&Gereffi, G (2014).Burundi in the Agribusiness Global Value Chain.Skills for Private Sector Development.

Banful, AfuaBranoah.(2011). "Old Problems in the New Solutions?Politically Motivated Allocation of Program Benefits and the "New" Fertilizer Subsidies." World Development, 39(7): 1166-1176.

Beck, Thorsten, Asli Demirguc-Kunt, and Ross Levine.(2005). SMEs, Growth, and Poverty: Cross-Country Evidence. Journal of Economic Growth, 10(1), 197-227.

Breckova, P. 2016. SMEs Export Activities in the Czech Republic and Export Risk Insuring. European Research Studies Journal, 19(1), 84-92.

Břečková, P. and Havlíček, K. 2013. Leaders Management and Personnel Controlling in SMEs. European Research Studies Journal, 16 (4), Special Issue on SMEs.

Chidoko, C., Makuyana, G., Matungamire, P., \&Bemani, J., (2011). Impact of the Informal Sector on the Current Zimbabwean Economic Environment.International. Journal of Economics and Research.www.ijeronline.compp 26-28.

Cohen, J. (1988). Statistical power analysis for the behavioral sciences (2nd ed.). New Jarsey: Lawrence Erlbaum Associates, Publishers. doi: 10.1234/12345678 Enterprise Baseline Survey. (2012).

Dionco-Adetayo, E.A., Awoniyi, M.O., Adetayo, J.O. and Elumilade, D.O. 2006. Enterprise Promotion Policy on The Development of Small Scale Industries in Nigeria: An Assessment. Refereed Paper; SME-Entrepreneurship Global Conference.

Garikai, B.W. 2011. Growth of SMEs in Developing Nations: Special Reference to AGOA. COMESA, Lusaka. Zambia.

Hamid, EdySuandi and Susilo, Sri. 2011. StrategiPengembangan Usaha Mikro Kecil dan Menengah di Provinsi Daerah Istimewa Yogyakarta.JurnalEkonomi Pembangunan, $12(1), 45-55$.

Hassan M.A and Olaniran S.O. 2011. Small Business Entrepreneurs Through Assistance Institutions: the Role of Industrial Development Centre, Osogbo, Nigeria. International Journal of Business and Management, 6(2), 213-226.

Havlíček, K., Thalassinos I.E. and Berezkinova, L. 2013.Innovation Management and Controlling in SMEs.European Research Studies Journal, 16(4), 57-70, Special Issue on SMEs.

Helisek, M. 2016. Supporting Small and Medium-sized Enterprises in Preparing for the Euro Adoption in the Czech Republic. European Research Studies Journal, 19(4), 27-41.

Hooi, L.W. 2006.Implementing e-HRM: The readiness of SME Manufacturing Company in Malaysia. Asia Pacific Business Review, 12(4), 465-485.

Katua, N. T. 2014. The Role of SMEs in Employment Creation and Economic Growth in Selected Countries.International Journal of Education and Research, 2(12). 
Kira, Alex Reuben. 2013. Determinants of Financing Constraints in East African Countries' SMEs. International Journal of Business and Management, 8(8).

Kongolo, M. 2010. Job Creation Versus Job Shedding and The Role of SMEs in Economic Development. African Journal of Business Management, 4(11), 2288-2295.

Mambula, C. 2002. Perceptions of SME Growth Constraints in Nigeria. Journal of Small Business Management, 40(1), 58-65.

Obasan, Kehinde A. and Kareem A. Arikewuyo. 2012. The Effect of Pre-post Bank Consolidation on The Accessibility of Finance to SMEs in Nigeria. Journal and Management Research, 1(3), 108-120.

Ogujiuba, K., Fadila, J. and Stiegler, N. 2013. Challenges of Microfinance Access in Nigeria: Implications for Entrepreneurship Development. Mediterranean Journal of Social Sciences, 4(6), 611-618.

Omar, S., Arokiasamy, L. and Ismail, M. 2009. The Background and Challenges Faced by The Small Medium Enterprises. A Human Resource Development Perspective.International Journal of Business and Management, 4(10).

Quaye, I, Abrokwah, E., Sarbah, A., and Osei, J. Y. (2014).Bridging the SME Financing Gap in Ghana: The Role of Microfinance Institutions. Journal of Business and Management.

Susilo, Sri Y. 2010. PeranPerbankanDalamPembiayaan UMKM di Propinsi DIY. Journal KeuangandanPerbankan, 14(3), 467-478.

Tcvetkov M., Tcvetkova I. and Chkalova O. (2015). Transaction Costs under Globalization: The Example of Russian Economy. European Research Studies Journal, 18(2), 107116.

Thalassinos, I.E., Pintea, M., Raţiu, I.P. (2015). The Recent Financial Crisis and Its Impact on the Performance Indicators of Selected Countries during the Crisis Period: A Reply. International Journal of Economics and Business Administration, 3(1), 3-20.

Theriou, G.N. (2015). Strategic Management Process and the Importance of Structured Formality, Financial and Non-Financial Information. European Research Studies Journal, 18(2), 3-28.

Uremadu, S. O. Ani, O. I. and Odili, O. (2014). Banking System Credit to Small and Medium Scale Enterprises (SMEs) and Economic Growth in Nigeria: A Co-integration Approach. IOSR Journal Economics and Finance, 5(6).

Yusuf, T.O. and Dansu, F.S. (2013).SMEs, Business Risks and Sustainability in Nigeria. European Journal of Business and Social Sciences, 2(9), 76-94. 